\title{
Essential Oils from Two Endemic Species of Apiaceae from Iran
}

Narguss Yassa ${ }^{a}$, Hossein Akhani ${ }^{b} *$, Majid Aqaahmadi ${ }^{b}$, and Mojtaba Salimian ${ }^{b}$

a Tehran University of Medical Science, Faculty of Pharmacy, Department of

Pharmacognosy, Tehran, Iran

b Tehran University, Faculty of Science, Department of Biology, PO Box 14155-6455,

Tehran, Iran. Fax: 0098-21-6405141. E-mail: akhani@khayam.ut.ac.ir

* Author for correspondence and reprint requests

Z. Naturforsch. 58c, 459-463 (2003); received January 8/February 14, 2003

The composition of essential oils of Leutea glaucopruinosa (Rech.f.) Akhani \& Salimian comb. nov., and Zeravschania (Boiss. \& Hausskn.) Salimian \& Akhani comb. nov. were analysed by GC-MS. 49 compounds are identified in the former and 33 compounds in the latter, comprising a total of 76 compounds in both species. Both species were originally described under Peucedanum, which are transferred in this paper into Leutea and Zeravschania, respectively. The chemical compounds of the essential oils show that there are only seven common compounds between two species. The major compounds of L. glaucopruinosa are mostly monoterpene hydrocarbons and oxygenated monoterpenes, in which $\alpha$-pinene $(31.5 \%)$, sabinene $(9.7 \%), \beta$-pinene $(9.2 \%)$, exo-fenchyl acetate $(4.5 \%)$ are dominant. In Z. pastinacifolia sesquiterpene hydrocarbons and phenylpropanoids dominate with $\beta$-bisabolene $(37.3 \%)$, 3,1-butyl-1,2-dimethoxy benzene (14.9\%), 10,11-dimethylbicyclo[6.3.0]undec-(8)-en-9-one $(12.9 \%), 4$ - $t$-butyl-1,2-dimethoxy benzene $(6.8 \%),(E)$-asarone $(5.1 \%)$ and elemicine $(4.1 \%)$ as major compounds.

Key words: Leutea, Zeravschania, Chemotaxonomy

\section{Introduction}

Species of the parsley family (Apiaceae) are well known with regards to their economic importance and diversity of essential oils (Hegnauer, 1971, 1973). This family is well represented in the Iranian flora at least with 112 genera, 316 species and 75 endemic species (Hedge et al., 1987). Peucedanum s. 1. is among the most critical group of Iranian Apiaceae which has been splitted into several genera in Flora Iranica (Pimenov, 1987). This is a first report of a series of papers related to the biochemical and biosystematical studies of Peucedanum sensu lato (including Peucedanum sensu stricto, Leutea and Zeravschania) in Iran. Leutea glaucopruinosa is a rock inhabiting species known from the vertical rocks in Golestan and Mazandaran Provinces in N. Iran which belongs to the Hyrcanian province of Euro-Siberian region (Fig. 1). This species was originally described under Peucedanum (Rechinger, 1952; Hedge et al., 1987). Zeravschania pastinacifolia is an endemic species in Central parts of Iran and grows on more or less rocky and scree steep slopes of the Central parts of Iran (Fig. 1). It was originally described under Peucedanum (Boissier, 1872). It was trans- ferred to the monotypic genus Demavendia (Pimenov, 1997), but our detailed studies showed that this should be transferred to Zeravschania.

\section{Nomenclature and Plant Materials}

The species studied in this paper are variously interpreted by different authors (Pimenov, 1987; Boissier, 1872). Based on the intensive taxonomical, anatomical and pollen morphological studies (Akhani and Salimian, in prep.), the generic concept of the members of Peucedanum complex in Iran is critically revised. Based on this studies the generic status of two species Peucedanum glaucopruinosum Rech. f., and Demavendia pastinacifolia (Boiss. \& Hausskn.) Pimenov (Syn.: Peucedanum pastinacifolium Boiss. \& Hausskn.) needs to be changed. In order to avoid future confusion, in this paper we follow the rules of the International Code of Botanical Nomenclature (Greuter et al,. 2000), and give the new generic status of the species:

\section{Leutea glaucopruinosa (Rech. f.) Akhani \&} Salimian comb. nov.

Basionym: Peucedanum glaucopruinosum Rech. f., Anz. Math.-Nat. Kl. Österr. Akad. Wiss. 89, 243 (1952). 
Zeravschania pastinacifolia (Boiss. \& Hausskn.) Salimian \& Akhani comb. nov.

Basionym: Peucedanum pastinacifolium Boiss. \& Hausskn. in Boiss., Diagn. Pl. Or. Nov. Ser. 1, 10, 35 (1849).

Voucher specimens for phytochemical analyses are provided for both species and are deposited in the Faculty of Science, University of Tehran under No. 15015 for L. glaucopruinosa and No. 15226 for Z. pastinacifolia, respectively.

\section{GC/MS analyses}

The arial parts of examined plants were dried in shadow at room temperature and $121 \mathrm{~g}$ of Leutea glaucopruinosa and $49.3 \mathrm{~g}$ of Zeravschania pastinacifolia powdered plants were hydrodistilled with a clevenger type apparatus for $4-5 \mathrm{~h}$. The yellowish oil was collected and dehydrated by anhydrous sodium sulfate. The volume of this oil was $0.71 \mathrm{ml} /$ $100 \mathrm{~g}$ dried plant material for Zeravschania pastinacifolia and $0.5 \mathrm{ml} / 100 \mathrm{~g}$ dried plant material for Leutea glaucopruinosa. The oil was analysed by GC/MS on a HEWLETT-PACKARD 6890 gas chromatograph coupled a mass detector (HEWLETT-PACKARD model 6973 HP). The column for oil separation use a fused silica HP-5 column, $30 \mathrm{~m}$ length, $250 \mu$ i.d., and $0.32 \mathrm{~mm}$ film thickness. The mass spectra were obtained by electron ionization at $70 \mathrm{eV}$. The oven temperature program was $60^{\circ} \mathrm{C}(30 \mathrm{~min})$ isotherm, then to $250^{\circ} \mathrm{C}$ at $5^{\circ} \mathrm{C} / \mathrm{min}$. The injector temperature was $250^{\circ} \mathrm{C}$.

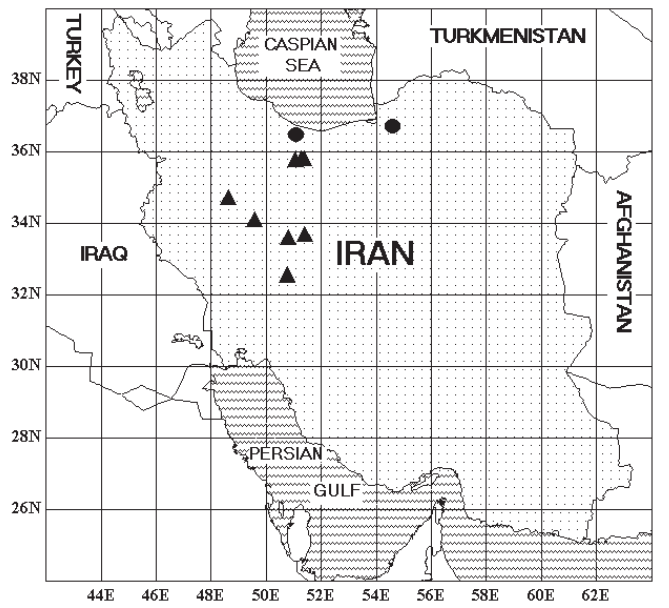

Fig. 1. Distribution maps of Leutea gaucopruinosa (dot) and Zeravschania pastinacifolia (triangle).
The carrier gas (helium) flow rate was $1 \mathrm{ml} / \mathrm{min}$. The sample $(1 \mathrm{ml})$ was injected with a split ratio of $1 / 90$. The compounds were identified using the Wiley 275 library, retention indices and MS fragmentation with published data (Adams, 1995).

\section{Results and Discussion}

According to the GC mass analysis a total of 76 compounds were identified in Leutea glaucopruinosa and Zeravschania pastinacifolia together. L. glaucopruinosa with 49 compounds included $55.7 \%$ monoterpene hydrocarbons, $18.7 \%$ oxygenated monoterpenes, $7.1 \%$ sesquiterpene hydrocarbons and 5\% oxygenated sesquiterpenes, together $88 \%$ of the total oils.

The major compounds of this species are $\alpha$-pinene $(31.5 \%)$, sabinene $(9.7 \%), \beta$-pinene $(9.2 \%)$, exo-fenchyl acetate $(4.5 \%)$, (-)-bornyl acetate $(3.6 \%)$, limonene $(2.6 \%)$, epi-ligulyloxide $(2.6 \%)$, $(Z)$-verbenol $(2.5 \%)$ and myrtenal $(2.3 \%)$. Previously only the oils of Leutea petiolaris (DC.) Pimenov (under Peucedanum petiolare (DC.) Boiss.) was reported (Rustaiyan et al., 2001). Among ten reported compounds, sabinene $(57.8 \%)$, $\delta$-3-carene $(36.2 \%)$ were identified as major compounds followed by $(E)-\beta$-ocimene $(1.8 \%)$, camphene $(0.5 \%), \beta$-pinene $(0.6 \%), p$-cymene $(0.1), \gamma$-terpinen $(0.1 \%)$, myrtenol $(0.2 \%)$, trans-carveol $(0.2 \%)$ and thymol $(0.1 \%)$. Seven compounds are similar between L. glaucopruinosa and L. petiolaris with various quantities. The published reports of essential oils in other members of Peucedaneae and one Apieae show that $\alpha$-pinene is a major compound in Prangos ferulacea (12.6\%) (Sefidkon et al., 1998), Peucedanum palustre (50.3\%) (Schmaus et al., 1989), P. verticillare (6.3\%) (Fraternale et al., $2000)$, and fruits of $P$. oreoselnium (5.1-8.3\%) (Motskute and Nivinskene, 1999). Sabinene was reported as a major compound in $P$. verticillare (39.6\%) (Fraternale et al., 2000), P. ostruthium (4.7\% in herb and $35.2 \%$ in rhizome) (Cisowski et al., 2001), and P. lancifolium (7.34\%), (Kubeczka et al., 1989). $\beta$-pinene was detected as a major compound in P. zenkeri ( $6.2 \%$ in leaves) (Menut et al., 1995), and P. oreoselnium (1.5-15.5\%) (Motskute and Nivinskene, 1999).

The oils of $Z$. pastinacifolia are composed of 33 compounds. This is apparently the first chemical report in the genus Zeravschania. There are large 
Table I. Chemical constituents of the essential oils of Leutea glaucopruinosa and Zeravschania pastinacifolia.

\begin{tabular}{|c|c|c|c|}
\hline Compound & $\mathrm{RI}^{\mathrm{a}}$ & $\begin{array}{l}\text { Leutea glauco- } \\
\text { pruinosa }(\%)\end{array}$ & $\begin{array}{l}\text { Zeravschania pasti- } \\
\text { nacifolia }(\%)\end{array}$ \\
\hline$\alpha$-Thujene & 0937 & 0.2 & - \\
\hline$\alpha$-Pinene & 0945 & 31.5 & 0.4 \\
\hline Camphene & 0959 & 0.3 & - \\
\hline Verbenene & 0965 & 0.4 & - \\
\hline Sabinene & 0986 & 9.7 & - \\
\hline$\beta$-Pinene & 0990 & 9.2 & 0.2 \\
\hline Myrcene & 1001 & 0.3 & 0.1 \\
\hline$\alpha$-Phellandrene & 1014 & - & $\operatorname{tr}$ \\
\hline$\alpha$-Terpinene & 1028 & 0.3 & $\operatorname{tr}$ \\
\hline$o$-Cymene & 1036 & 0.4 & - \\
\hline Limonene & 1040 & 2.6 & 0.7 \\
\hline$(Z)$ - $\beta$-ocimene & 1048 & $\operatorname{tr}$ & $\operatorname{tr}$ \\
\hline (E)- $\beta$-Ocimene & 1060 & - & 0.6 \\
\hline$\gamma$-Terpinene & 1068 & 0.7 & - \\
\hline Terpinolene & 1097 & 0.1 & 0.3 \\
\hline Linalool & 1108 & 0.3 & - \\
\hline$\alpha$-Campholene aldehyde & 1132 & 0.6 & - \\
\hline (E)-Pinocarveol & 1145 & 1.1 & - \\
\hline (Z)-Verbenol & 1146 & 2.5 & - \\
\hline$\beta$-Phellandrene-8- 01 & 1154 & 0.3 & - \\
\hline d-Pinocarvone & 1166 & 0.8 & - \\
\hline Lavandulol & 1170 & - & 0.4 \\
\hline$\alpha$-Phellandrene- 8 -ol & 1171 & 0.9 & - \\
\hline Terpinene-4-ol & 1180 & 1.1 & - \\
\hline Myrtenal & 1196 & 2.3 & - \\
\hline Verbenone & 1208 & 0.7 & - \\
\hline iso-Thymol methyl ether & 1215 & - & 0.7 \\
\hline exo-Fenchyl acetate & 1230 & 4.5 & - \\
\hline Thymol methyl ether & 1240 & - & 0.5 \\
\hline$o$-Hydroxy cumene & 1260 & - & 0.2 \\
\hline (-)-Bornyl acetate & 1284 & 3.6 & - \\
\hline Lavandulyl acetate & 1294 & - & 0.7 \\
\hline$\alpha$-Cubebene & 1357 & $\operatorname{tr}$ & - \\
\hline$\alpha$-Longipinene & 1360 & $\mathrm{tr}$ & - \\
\hline Cyclosativene & 1368 & 0.6 & - \\
\hline Cyclofenchene & 1372 & - & 0.1 \\
\hline$\alpha$-Copaene & 1380 & 0.6 & - \\
\hline$\beta$-Cubebene & 1390 & 0.7 & - \\
\hline 4,5-Dimethoxy-2-(2-propyl)phenol & 1400 & - & 1.4 \\
\hline Methyl eugenol & 1409 & - & 0.1 \\
\hline (-)-Sinularene & 1415 & 0.1 & - \\
\hline iso-Longifolene & 1419 & 0.1 & - \\
\hline (E)- $\beta$-Caryophyllene & 1425 & 0.4 & - \\
\hline 3,1-Butyl-1,2-dimethoxy benzene & 1428 & - & 14.9 \\
\hline$\beta$-Gurjunene & 1434 & 0.5 & - \\
\hline$\gamma$-Elemene & 1436 & - & 0.2 \\
\hline 4-t-Butyl-1,2-dimethoxy benzene & 1438 & - & 6.8 \\
\hline (E)- $\alpha$-Bergamotene & 1440 & - & 0.2 \\
\hline $\begin{array}{l}\text { 3H-Cyclopenta[a]pentalen-3-one- } \\
\text { 1,2,3a,5,6,6a,7,7a-octahydro-3a,5,5- } \\
\text { trimethyl-(3a. } \alpha, 6 \mathrm{a} . \beta, 7 \mathrm{a} . \alpha)\end{array}$ & 1446 & 1.6 & - \\
\hline$\alpha$-Humulene & 1456 & 0.1 & - \\
\hline (Z)-Methyl eugenol & 1461 & - & 0.3 \\
\hline 10,11-Dimethylbicyclo[6.3.0]undec-(8)-en-9-one & 1470 & - & 12.9 \\
\hline Aristolene & 1472 & 0.2 & - \\
\hline Germacrene-D & 1482 & 0.2 & - \\
\hline$\gamma$-Selinene & 1483 & 0.4 & - \\
\hline$\beta$-Selinene & 1485 & 1.1 & - \\
\hline Valencene & 1490 & 0.5 & - \\
\hline
\end{tabular}


Table I. (cont.)

\begin{tabular}{|c|c|c|c|}
\hline Compound & $\mathrm{RI}^{\mathrm{a}}$ & $\begin{array}{l}\text { Leutea glauco- } \\
\text { pruinosa }(\%)\end{array}$ & $\begin{array}{l}\text { Zeravschania pasti- } \\
\text { nacifolia }(\%)\end{array}$ \\
\hline$\alpha$-Selinene & 1494 & 0.7 & - \\
\hline (E)-Methyl eugenol & 1500 & - & 5.6 \\
\hline$\alpha$-Muurolene & 1506 & 0.6 & - \\
\hline Germacrene-A & 1509 & 0.1 & - \\
\hline$\beta$-Bisabolene & 1513 & - & 37.3 \\
\hline 7-Epi- $\alpha$-selinene & 1518 & 0.1 & - \\
\hline Myristicin & 1525 & - & 0.1 \\
\hline$\delta$-Cadinene & 1530 & 0.1 & - \\
\hline Epi-ligulyloxide & 1535 & 2.6 & - \\
\hline Elemicine & 1560 & - & 4.1 \\
\hline Germacrene-B & 1563 & - & 1.7 \\
\hline Benzene-1,2,3,4-tetramethoxy-5-(propenyl) & 1570 & - & 0.2 \\
\hline Spathulenol & 1581 & 1.3 & - \\
\hline$(Z)-\beta$-Asarone & 1626 & - & 0.4 \\
\hline Dillapiol & 1628 & - & 0.4 \\
\hline$(E)$-isoelemicine & 1650 & - & 0.2 \\
\hline$\alpha$-Eudesmol & 1660 & 1.1 & - \\
\hline$(E)$-Asarone & 1681 & - & 5.1 \\
\hline Monoterpene hydrocarbons & & 55.7 & 2.3 \\
\hline Oxygenated monoterpenes & & 18.7 & 1.1 \\
\hline Sesquiterpene hydrocarbons & & 7.1 & 43.8 \\
\hline Oxygenated sesquiterpenes & & 5.0 & 5.1 \\
\hline Phenylpropanoids & & - & 31.6 \\
\hline Others & & 1.6 & 12.9 \\
\hline Total & & 88.1 & 96.8 \\
\hline
\end{tabular}

$\operatorname{tr}=\operatorname{trace}<0.1 \%$.

a Retention index on the HP5 column.

differences in the oil constituents of Z. pastinacifolia and L. glaucopruinosa. Only 7 compounds including $\alpha$-pinene, $\beta$-pinene, myrcene, limonene, $(Z)$ - $\beta$-ocimene and $\alpha$-terpinene and terpinolene present in both species, however, with very different quantities (Table I). In Z. pastinacifolia, sesquiterpene hydrocarbons dominates with $43.8 \%$, with a high percentage of phenylpropanoids $(31 \%)$ and lower percentage of monoterpene hydrocarbons $(2.3 \%)$ and oxygenated sesquiterpenes $(5.1 \%)$. The major compound is $\beta$-bisabolene with $37.3 \%$. Other major compounds include 3,1-butyl1,2-dimethoxy benzene (14.9\%), 10,11-dimethylbicyclo[6.3.0]undec-(8)-en-9-one (12.9\%), 4-t-butyl-1,2-dimethoxy benzene $(6.8 \%),(E)$-asarone $(5.1 \%)$ and elemicine $(4.1 \%)$. It is surprising that none of these compounds were distinguished in Leutea glaucopruinosa, which is a good reason for their taxonomic distance. By literature survey we could not find a close similarity in oils of $Z$. pastinacifolia and any other member of Peucedanum and related genera. The major compound $\beta$-bisabolene was reported as a trace compound in fresh $(0.8 \%)$ and dried fruits $(2.0 \%)$ of $P$. verticillare (Fraternale et al., 2000) and fruits of P. oreoselinum with only $0.05-0.10 \%$ (Motskute and Nivinskene, 1999).

\section{Acknowledgements}

This research was partly supported by Research Council University of Tehran under project number 513/4/520. A three months research award by DAAD (German Academic Exchange Service) for $\mathrm{H}$. A. facilitated the final preparation of this contribution. 
Adams D. R. (1995), Identification of essential oil components by GC/MS spectroscopy . Allured Publ., Illinois, USA.

Boissier E. (1872), Flora Orientalis. Vol. 2. Geneve.

Cisowski W., Sawicka U., Mardarowicz M., Asztemborska M., and Łuczkiewicz M. (2001), Essential oil from herb and rhizome of Peucedanum ostruthium (L. Koch) ex DC. Z. Naturforsch. 56c, 930-932.

Fraternale D., Giamperi L., Ricci D., and Manunta A. (2000), Composition of the essential oil of Peucedanum verticillare. Bioch. Sys. Ecol. 28, 143-147.

Greuter W., Mcneill J., Barrie F. R., Burdet H. M., Demoulin V., Filgueiras T. S., Nicolson D. H., Silva P. C., Skog J. E., Trehane P., Turland N. J., and Hawksworth D. L. (eds) (2000), International Code of Botanical Nomenclature (Saint Louis Code). Regnum Vegetabile, 138. Koeltz Scientific Books, Königstein, Germany.

Hedge I. C., Lamond J. M., Rechinger K. H., Alava R., Chamberlain D. F., Engstrand L., Herrnstadt I., Heyn C. C., Leute G. H., Mandenova I., Peev D., Pimenov M. G., Snogerup S., and Tamamschian S. G. (1987), Umbelliferae. In: Flora Iranica (Rechinger K. H., ed.), Vol. 162. Akademische Druck- u. Verlagsanstalt Graz, Austria.

Hegnauer R. (1971), Chemical patterns and relationships of Umbelliferae. In: The Biology and Chemistry of Umbelliferae (Heywood V.H., ed.). Academic Press, New York, pp. 267-277.

Hegnauer R. (1973), Chemotaxonomie der Pflanzen. 6. Rafflesiaceae-Zygophyllaceae. Birkhäuser Verlag, Basel und Stuttgart.
Kubeczka K.-H., Schmaus G., Schultze W., and Ullmann I. (1989), The essential oil of Peucedanum lancifolium Lange and chemotaxonomic implications. Z. Naturforsch. 44c, 183-188.

Menut C., Eyele Mve-Mba C., Lamaty G., Amvam Zollo P.-H., Tchoumbougnang F., and Bessiere J.-M. (1995), Aromatic plants of tropical central Africa. XVIII. Essential oils of leaf and rhizome of Peucedanum zenkeri Engl. from Cameroon. J. Essent. Oil Res. 7, $77-79$.

Motskute D. and Nivinskene O. (1999), Essential oil of Peucedanum oreoselinum fruits collected near Vilnius. Chem. Nat. Comp. 35, 635-637.

Pimenov M. G. (1987), Leutea (pp. 445-450), Demavendia (pp. 450-451), Cervaria (pp. 451-454), Johreniopsis (pp. 454-457) and Zeravschania (pp. 457-462) [Umbelliferae]. In: Flora Iranica (Rechinger K. H., ed.), Vol. 162. Akademische Druck- u. Verlagsanstalt, Graz, Austria.

Rechinger K. H. (1952), Umbelliferae novae iranicae, I. Anz. math.-naturw. Kl. Österr. Akad. Wiss. 89, 168176.

Rustaiyan A., Komeilizadeh H., Mojab F., Khazae A., Masoudi S., and Yari M. (2001), Essential oil composition of Peucedanum petiolare (DC.) Boiss., from Iran. J. Essent. Oil Res. 13, 49-50.

Schmaus G., Schultze W., and Kubeczka K. H. (1989), Volatile constituents of Peucedanum palustre. Planta Med. 55, 482-487.

Sefidkon F., Khajavi M. S., and Malackpour B. (1998), Analysis of the oil of Prangos ferulacea (L.) Lindl. J. Essent. Oil Res. 10, 81-82. 